\title{
SEQUENCE AND CHRONOLOGY OF TOOTH ERUPTION IN CHILDREN AND ADOLESCENTS FROM SANTA MARIA - SOUTHERN BRAZIL
}

\author{
CRONOLOGIA E SEQUENNCIA DA ERUPÇAO DENTÁRIA EM \\ CRIANÇAS E ADOLESCENTES DE SANTA MARIA-RS ${ }^{1}$
}

\author{
Danieli Londero da Silveira², Edes Marinho Cavalheiro ${ }^{3}$, \\ Cristiana Pereira Malta ${ }^{4}$ and Letícia Westphalen Bento ${ }^{5}$
}

\section{ABSTRACT}

The literature reports a standard chronological sequence in the eruption of permanent teeth. However, evidence indicates that regional differences may interfere in this process. Thus, the aim of the present study was to compare dental age and chronological age in children and adolescents in a city in southern Brazil to determine the specific pattern in this population. We analyzed the orthodontic records of 250 children and adolescents at the undergraduate course in dentistry of Universidade Franciscana in the city of Santa Maria (southern Brazil). The dental age of each individual was determined through the analysis of panoramic radiographs using the Nolla's method. Data were also collected on the child's chronological age, sex, and race. No significant difference was found between average chronological age and that determined using Nolla's method, indicating that dental and chronological age are similar in this population. However, the eruption periods of all tooth groups were slightly ahead in comparison to the world standard.

Keywords: Tooth eruption, chronology, development, chronology.

\section{RESUMO}

A literatura evidencia uma sequência cronológica padrão de erupção dos elementos dentários permanentes. Entretanto, evidências apontam que diferenças regionais podem interferir nesse processo. Dessa forma, o objetivo do presente estudo foi comparar a idade dentária com a idade cronológica de crianças e adolescentes de uma cidade do Sul do Brasil a fim de verificar o padrão específico para essa população. Para tanto, foram analisadas documentações ortodônticas de 250 crianças e adolescentes atendidos no Curso de Graduação em Odontologia da Universidade Franciscana, na cidade de Santa Maria - RS. Através das radiografias panorâmicas foi determinada a idade dentária de cada indivíduo a partir do método de Nolla. Além disso, foram coletados dados relativos a idade cronológica, sexo e raça. No presente estudo, não houve diferença estatística entre a média de idade cronológica e a determinada pelo método de Nolla, indicando que a idade dentária e a cronológica se assemelham na referida população. Além disso, a amostra analisada encontrou-se ligeiramente adiantada em relação aos períodos de erupção de todos os grupos dentários, quando comparada ao que consta como padrão mundial.

Palavras-chave: Erupção, cronologia, desenvolvimento, cronologia.

\footnotetext{
${ }^{1}$ Cross-sectional study

${ }^{2}$ Author. DDS, MSc - UFN/UFRGS. E-mail: danielilondero29@gmail.com

${ }^{3}$ Contributor. DDS - UFN. E-mail: edesmarinhocavalheiro@gmail.com

${ }^{4}$ Contributor. DDS, MSc - UFN/UFSM. E-mail: cris_malta@hotmail.com

${ }^{5}$ Adviser. Teaching staff member -. DDS, MSc, PhD - UFN - E-mail: leticiabento@ufn.edu.br
} 


\section{INTRODUCTION}

Tooth development (odontogenesis) begins in the sixth week of intrauterine life with the appearance of a primary epithelial band that divides into vestibular and dental laminas. The dental lamina, which will give rise to the future tooth germs, continues to develop, passing through the bud, cap, and bell stages, followed by the apposition and maturation stages. The period in which the germs go through each development phase varies among the different tooth groups (GOVORKO et al., 2010; MATALOVÁ et al., 2011).

The primary dentition is composed of 20 teeth and develops during the prenatal period, subsequently undergoing eruption and replacement. As the primary teeth undergo the process of ex foliation and the jaws (maxilla and mandible) grow, the 32 teeth that constitute the permanent dentition erupt, gradually replacing the primary teeth (BATH-BALOGH \& FEHRENBACH, 2008). In this natural process, the resorption of the roots of the primary teeth, denominated rhizolysis, begins three to four years prior to the eruption of the first permanent tooth in the oral cavity, varying according to each tooth group (GUEDES-PINTO, 2006).

During the growth and development that occurs with chronological age, biochemical, physiological and anatomic phenomena exert an influence on the process of dental and skeletal maturation, which is partially affected by environmental, nutritional, genetic, ethnic, hormonal, sexual, and metabolic factors. Thus, a certain degree of caution is required regarding the acceptance of standard parameters from one region to another (SILVA \& PEREIRA, 2005). It is of considerable importance to monitor the dental development of children, as this period involves a set of important mechanisms and processes, the understanding of which is fundamental to detecting possible occurrences outside the standards of normality (VASCONCELOS et al., 2012). Dental anomalies are peculiar to the dental structure, diagnosed at the time of clinical or radiographic evaluation. These are pointed out as changes in number, size, shape, position or structure and may even cause delay in the timing of eruption of teeth (WHITE \& PHAROAH, 2007).

As the determination of dental age is important to clinical decision making, the aim of the present study was to compare dental age to chronological age in children from a city in southern Brazil to provide updated data on these parameters that can help guide the clinical conduct of pediatric dentists and orthodontists.

\section{METHODS}

The present observational cross-sectional study received approval from the Human Research Ethics Committee of Universidade Franciscana (certificate number: 1.672.058). The sample consisted of the orthodontic records of 250 children and adolescents at the clinics of the undergraduate course 
in dentistry and postgraduate course in orthodontics of the university. We included all patients between three and 17 years of age with complete orthodontic documentation (panoramic x-ray and five intraoral photographs: frontal, upper/lower occlusal and left/right lateral) that enabled the evaluation of all teeth. Patients with systemic conditions or syndromes, those with active caries and records with any orthodontic artefacts were excluded.

The dental evaluation was based on occlusal intraoral and profile photographs (Figure 1). All teeth were recorded as either 0 (absent) or 1 (present, including semi-erupted teeth). The sex, race, and chronological age (in months) of the children and adolescents were also recorded. The panoramic radiographs in the orthodontic records were analyzed for the estimate of dental age. The formation stage of the seven permanent teeth of the right mandibular hemiarch was classified based on the 10 criteria established by Nolla (1960), in which Stage 1 indicates the presence of the tooth crypt and Stage 10 indicates the completion of the apical extremity (Figure 2). Dental age in years was estimated by summing this classification in a specific table for each sex, with the exclusion of the third molars. For greater precision and objectivity in this estimate, dental age (in years) in the table and the difference between the value corresponding to the sum of the stages of the seven mandibular teeth was subdivided into four three-month intervals (Table 1).

Table 1 - Table modified based on Nolla (1960).

Dental age every three months corresponding to the sum of the stages of tooth development.

\begin{tabular}{|c|c|c|c|c|c|c|c|}
\hline $\begin{array}{c}\text { Age } \\
\text { (years) }\end{array}$ & $\begin{array}{c}\text { Age } \\
\text { (month) }\end{array}$ & $\begin{array}{c}\text { Sum of stages } \\
\text { for } 7 \text { mandibular } \\
\text { teeth (Girls) }\end{array}$ & $\begin{array}{c}\text { Sum of stages } \\
\text { for } 7 \text { mandibular } \\
\text { teeth (Boys) }\end{array}$ & $\begin{array}{c}\text { Age } \\
\text { (years) }\end{array}$ & $\begin{array}{c}\text { Age } \\
\text { (month) }\end{array}$ & $\begin{array}{c}\text { Sum of stages } \\
\text { for } 7 \text { mandibular } \\
\text { teeth (Girls) }\end{array}$ & $\begin{array}{c}\text { Sum of stages } \\
\text { for } 7 \text { mandibular } \\
\text { teeth (Boys) }\end{array}$ \\
\hline 3 & 36 & 24.6 & 22.3 & 10 & 120 & 64.3 & 61.5 \\
\hline 3 to $3 \mathrm{~m}$ & 39 & 26.6 & 24.3 & 10 to $3 \mathrm{~m}$ & 123 & 64.8 & 62.1 \\
\hline 3 to $6 \mathrm{~m}$ & 42 & 28.6 & 26.3 & 10 to $6 \mathrm{~m}$ & 126 & 65.3 & 62.7 \\
\hline 3 to $9 \mathrm{~m}$ & 45 & 30.6 & 28.3 & 10 to $9 \mathrm{~m}$ & 129 & 65.8 & 63.4 \\
\hline 4 & 48 & 32.7 & 30.3 & 11 & 132 & 66.3 & 64 \\
\hline 4 to $3 \mathrm{~m}$ & 51 & 34.5 & 32 & 11 to $3 \mathrm{~m}$ & 135 & 66.7 & 64.5 \\
\hline 4 to $6 \mathrm{~m}$ & 54 & 36.4 & 33.7 & 11 to $6 \mathrm{~m}$ & 138 & 67.1 & 65.1 \\
\hline 4 to $9 \mathrm{~m}$ & 57 & 38.2 & 35.4 & 11 to $9 \mathrm{~m}$ & 141 & 67.5 & 65.7 \\
\hline 5 & 60 & 40.1 & 37.1 & 12 & 144 & 67.9 & 66.3 \\
\hline 5 to $3 \mathrm{~m}$ & 63 & 41.7 & 38.6 & 12 to $3 \mathrm{~m}$ & 147 & 68.1 & 66.7 \\
\hline 5 to $6 \mathrm{~m}$ & 66 & 43.3 & 40.05 & 12 to $6 \mathrm{~m}$ & 150 & 68.4 & 67.05 \\
\hline 5 to $9 \mathrm{~m}$ & 69 & 44.9 & 41.5 & 12 to $9 \mathrm{~m}$ & 153 & 68.6 & 67.4 \\
\hline 6 & 72 & 46.6 & 43 & 13 & 156 & 68.9 & 67.8 \\
\hline 6 to $3 \mathrm{~m}$ & 75 & 48 & 44.4 & 13 to $3 \mathrm{~m}$ & 159 & 69 & 68.1 \\
\hline 6 to $6 \mathrm{~m}$ & 78 & 49.5 & 45.85 & 13 to $6 \mathrm{~m}$ & 162 & 69.1 & 68.4 \\
\hline 6 to $9 \mathrm{~m}$ & 81 & 50.9 & 47.3 & 13 to $9 \mathrm{~m}$ & 165 & 69.2 & 68.7 \\
\hline 7 & 84 & 52.4 & 48.7 & 14 & 168 & 69.4 & 69 \\
\hline 7 to $3 \mathrm{~m}$ & 87 & 53.6 & 50 & 14 to $3 \mathrm{~m}$ & 171 & 69.5 & 69.1 \\
\hline 7 to $6 \mathrm{~m}$ & 90 & 54.9 & 51.2 & 14 to $6 \mathrm{~m}$ & 174 & 69.6 & 69.3 \\
\hline 7 to $9 \mathrm{~m}$ & 93 & 56.1 & 52.5 & $149 \mathrm{~m}$ & 177 & 69.7 & 69.5 \\
\hline 8 & 96 & 57.4 & 53.7 & 15 & 180 & 69.8 & 69.7 \\
\hline 8 to $3 \mathrm{~m}$ & 99 & 57.6 & 54.8 & 15 to $3 \mathrm{~m}$ & 183 & 69.85 & 69.75 \\
\hline
\end{tabular}




\begin{tabular}{cccccccc}
\hline 8 to $6 \mathrm{~m}$ & 102 & 57.9 & 55.8 & 15 to $6 \mathrm{~m}$ & 186 & 69.9 & 69.8 \\
\hline 8 to $9 \mathrm{~m}$ & 105 & 58.1 & 56.9 & 15 to $9 \mathrm{~m}$ & 189 & 69.95 & 69.9 \\
\hline 9 & 108 & 58.4 & 57.9 & 16 & 192 & 70 & 70 \\
\hline 9 to $3 \mathrm{~m}$ & 111 & 59.8 & 58.8 & 17 & 204 & 70 & 70 \\
\hline 9 to $6 \mathrm{~m}$ & 114 & 61.3 & 59.7 & & & & \\
\hline 9 to $9 \mathrm{~m}$ & 117 & 62.8 & 60.6 & & & & \\
\hline
\end{tabular}

All clinical and radiographic analyses were performed by the same examiner (D.L.S.), who had undergone training and calibration exercises. For such, five records were analyzed by the examiner and experienced pediatric dentist. Inter-examiner agreement was measured using the Kappa coefficient $(\mathrm{K}=0.90)$. For the determination of intra-examiner agreement, 10 records were evaluated on two occasions separated by a seven-day interval $(\mathrm{K}=0.93)$.

Data analysis was performed with the aid of the SPSS program, version 20. The results were analyzed descriptively. Mean age between girls and boys was compared using the t-test. Dental and chronological age of the children and adolescents were compared using the paired t-test.

Figure 1 - Intraoral occlusal and profile photographs of a patient used for the evaluation of present and absent teeth.
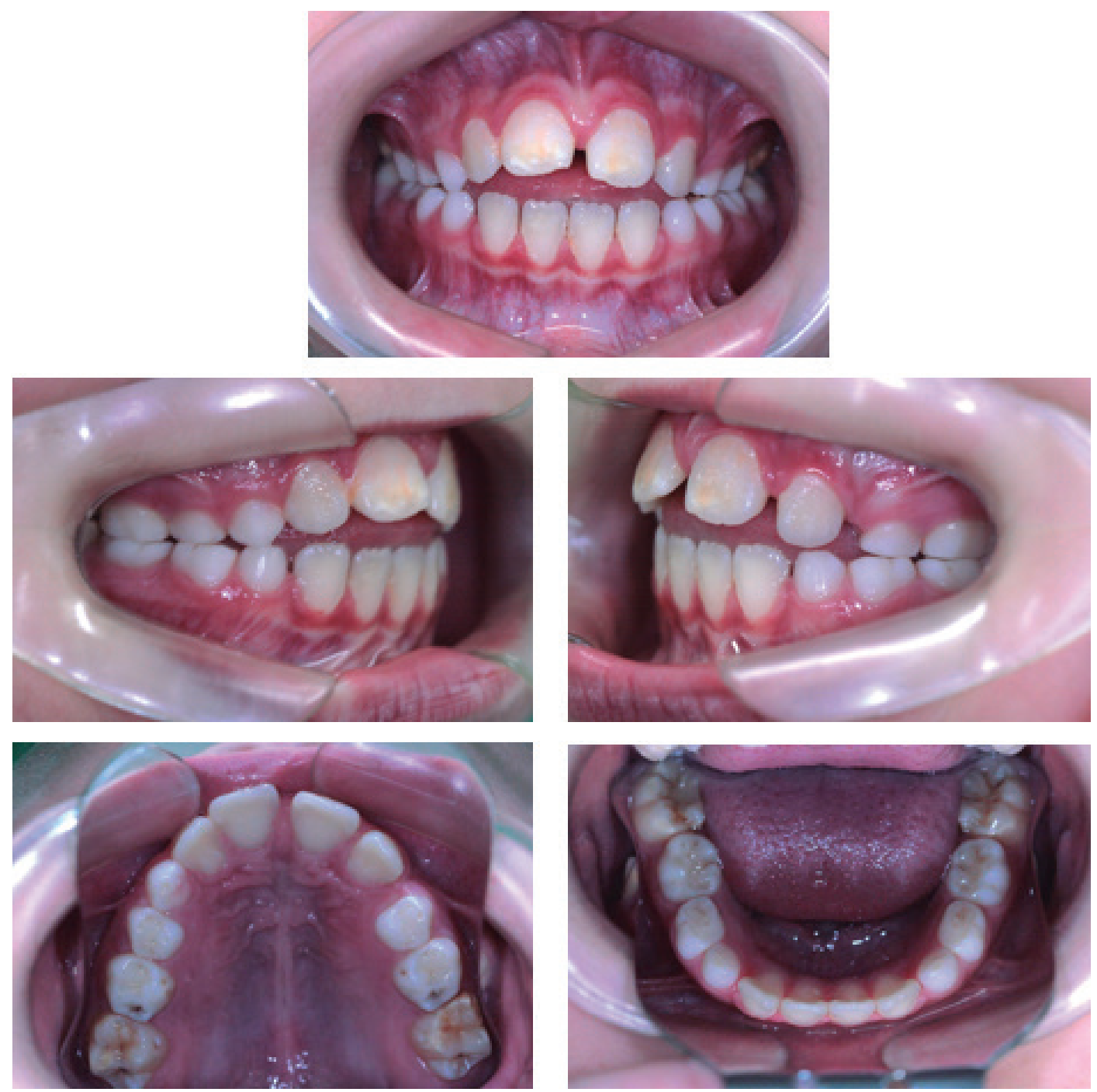
Figure 2 - Panoramic x-ray and classification of permanent teeth based on Nolla's 10 criteria.

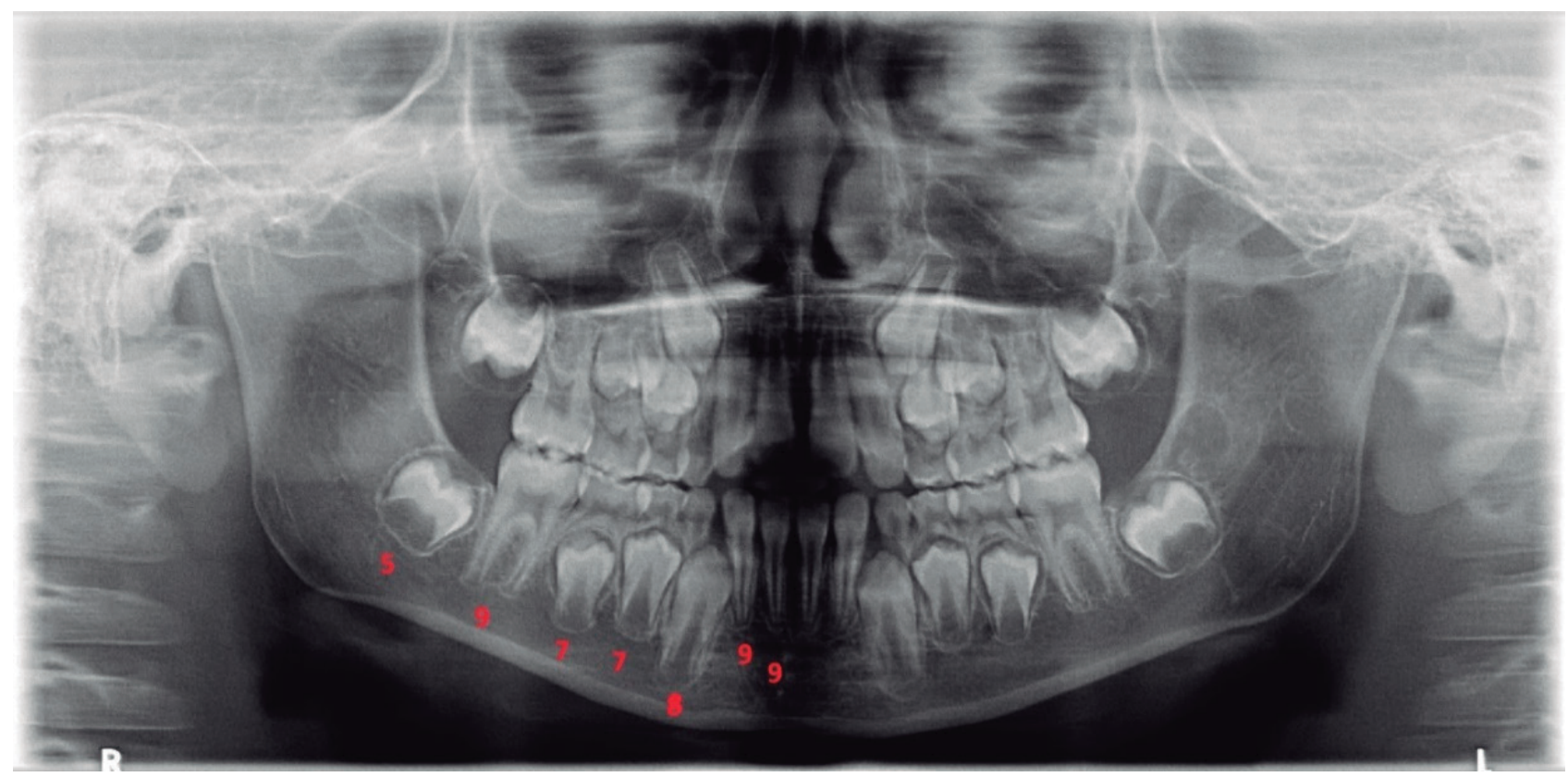

Chronological age of a male patient: 84 months (seven years). Dental age: sum of scores according to Nolla's classification system (1960): the sum $54(9+9+8+7+7+9+5)$ corresponds to dental age of 96 months (eight years).

\section{RESULTS}

The 250 orthodontic records analyzed in the present study belonged to 132 girls and 118 boys. Table 2 displays the data on sample size, sex, race, and age.

In the analysis regarding the presence of permanent teeth (Tables 3 and 4), maxillary first molars were present between 5.5 and 6 years and mandibular first molars were present at 5.5 years in both sexes, followed by mandibular incisors 6 years. Maxillary central incisors appeared, on average, at 6.5 years of age and the lateral incisors appeared at 7.5 years. The mandibular canines were present in the oral cavity at 7.5 to 8 years, whereas the maxillary canines were present at 9.5 to 10 years. The maxillary first and second premolars were present at around 8.5 years. The mandibular first premolars were present at 8 years of age and the mandibular second premolars were present around 9.5 years of age. The second molars were present around 11 years of age. No statistically significant difference between sexes was found regarding dental and chronological age $(\mathrm{p} \leq 0.05)$ (Table 2).

In the primary dentition, exfoliation of the maxillary incisors occurred at around six years of age. However, exfoliation of tooth 51 occurred a little later ( 7 years) in boys compared to girls. The mandibular incisors also initiated the exfoliation process at around 6 years of age. Exfoliation of the canines began between 8 and 9 years of age. Exfoliation of the first molars began around 8 years of age and exfoliation of the primary second molars occurred between 7 and 8 years of age. 
Table 2 - Clinical characteristics of sample, Santa Maria, RS, Brazil (N = 250)

\begin{tabular}{lccc}
\hline Characteristics & N & \% (Mean \pm SD) & p \\
\hline Ethnicity & 204 & 81.6 & \\
White & 40 & 16.0 & \\
Black & 6 & 2.4 & \\
Yellow & & & \\
Chronological age & 132 & $118.62 \pm 30.1$ & 0.05 \\
Girls & 118 & $117.93 \pm 27.8$ & \\
Boys & & & \\
Age (boys) & & $117.93 \pm 27.8$ & 0.05 \\
$\begin{array}{l}\text { Chronological age (months) } \\
\text { Age by Nolla's method }\end{array}$ & & $117.48 \pm 32.1$ & \\
$\begin{array}{l}\text { Age (girls) } \\
\text { Chronological age (months) }\end{array}$ & & $118.62 \pm 30.1$ & 0.05 \\
Age by Nolla's method & & $116.18 \pm 34.6$ & \\
$\begin{array}{l}\text { Age (both sexes) } \\
\text { Chronological age (months) }\end{array}$ & & $118.30 \pm 28.9$ & \\
Nolla's method & $116.80 \pm 33.4$ & 0.05 \\
\hline
\end{tabular}

Source: Author

Table 3 - Permanent teeth present according to age and sex

\begin{tabular}{cccc}
\hline Teeth & Age (both sexes) & Girls & Boys \\
\hline $46 \_36$ & 5.5 & 5.5 & 5.5 \\
\hline $16 \_26$ & $5.5 \_6$ & 6 & 5.5 \\
\hline $41 \_31$ & 6 & 6 & 6 \\
\hline $42 \_32$ & 6 & 6 & 6 \\
\hline $11 \_21$ & 6.5 & 6.5 & 6.5 \\
\hline $12 \_22$ & 7.5 & 7.5 & 7.5 \\
\hline $43 \_33$ & $7.5 \_8$ & 7.5 & 8 \\
\hline $44 \_34$ & 8 & 8 & 8 \\
\hline $14 \_24$ & 8.5 & 8.5 & 8.5 \\
\hline $15 \_25$ & 8.5 & 8.5 & 8.5 \\
\hline $45 \_35$ & 9.5 & 9.5 & 9.5 \\
\hline $13 \_23$ & $9 \_10.5$ & 9 & 10.5 \\
\hline $47 \_37$ & 11 & 11 & 11 \\
\hline $17 \_27$ & 11 & 11 & 11 \\
\hline
\end{tabular}

Source: Author 
Table 4 - Minimum and maximum age (in months) at presence of permanent teeth.

\begin{tabular}{|c|c|c|c|c|c|}
\hline \multirow{2}{*}{\multicolumn{2}{|c|}{ Teeth }} & \multicolumn{2}{|c|}{ Girls } & \multicolumn{2}{|c|}{ Boys } \\
\hline & & Minimum & Maximum & Minimum & Maximum \\
\hline \multirow{7}{*}{ 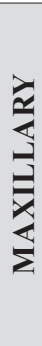 } & $11 / 21$ & $81 / 81$ & $171 / 171$ & $79 / 79$ & $120 / 120$ \\
\hline & $12 / 22$ & $90 / 88$ & $154 / 171$ & $84 / 84$ & $130 / 137$ \\
\hline & $13 / 23$ & $112 / 104$ & $163 / 170$ & $103 / 103$ & $162 / 169$ \\
\hline & $14 / 24$ & $82 / 82$ & $148 / 158$ & $102 / 103$ & $156 / 169$ \\
\hline & $15 / 25$ & $104 / 104$ & $170 / 170$ & $102 / 103$ & $162 / 169$ \\
\hline & $16 / 26$ & $82 / 70$ & $127 / 127$ & $69 / 69$ & $119 / 113$ \\
\hline & $17 / 27$ & $129 / 140$ & $182 / 191$ & $124 / 131$ & $204 / 204$ \\
\hline \multirow{7}{*}{ 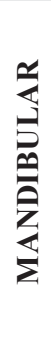 } & $31 / 41$ & $58 / 58$ & $106 / 106$ & $69 / 69$ & $101 / 101$ \\
\hline & $32 / 42$ & $80 / 80$ & $154 / 154$ & $79 / 79$ & $125 / 125$ \\
\hline & $33 / 43$ & $92 / 92$ & $143 / 143$ & $103 / 103$ & $145 / 143$ \\
\hline & $34 / 44$ & $96 / 82$ & $158 / 158$ & $103 / 103$ & $169 / 169$ \\
\hline & $35 / 45$ & $112 / 82$ & $170 / 170$ & $103 / 103$ & $169 / 169$ \\
\hline & $36 / 46$ & $82 / 82$ & $143 / 143$ & $69 / 79$ & $142 / 162$ \\
\hline & $37 / 47$ & $102 / 110$ & $182 / 189$ & $111 / 111$ & $204 / 204$ \\
\hline
\end{tabular}

Source: Author

\section{DISCUSSION}

The study of human development is of extreme importance. Understanding each step is fundamental to distinguishing physiological from pathological processes and guiding healthcare providers to more effective actions. According to Seabra et al. (2008) diagnosing dental anomalies is not always possible only with the clinical examination, hence a radiographic examination is necessary to confirm or diagnose any dental alteration. These changes are manifested with different degrees of severity, which can be represented from a chronological delay in dentition, to a complete absence of tooth germ or agenesis (GARIB et al., 2010). The periods of skeletal and dental maturation involve a set of mechanisms and processes, the knowledge of which enables the detection of aspects and occurrences outside the standards of normality (SILVA \& PEREIRA, 2005). According to Sosa et al. (2006), most dental anomalies occur between the sixth and eighth week of intrauterine life, since it is at this stage that important structures such as the dental papilla and the dental organ begin their histodifferentiation and form enamel, dentin and cementum. McDonald et al. (2011) refers that in eruption anomalies, a variety of developmental defects are evident after the eruption of deciduous and permanent teeth and may be related to local and systemic factors that influence the formation of the matrix and the calcification process. In dentistry, understanding the relation between dental and chronological age plays an important role in clinical decision making, especially in the fields of pediatric dentistry and orthodontics. As there is a need for current, regional studies on tooth eruption, the present study was developed to determine the eruption chronology of the permanent teeth, determine dental age, and compare dental age to chronological age in children and adolescents from a city in southern Brazil. 
The sample was evenly distributed between the sexes. Regarding age group, however, a greater concentration was found of children between seven and 11 years. This occurred due to the fact that the patients were initiating preventive/interceptive orthodontic treatment, which explains the requests for orthodontic documentation. The small number of non-white individuals in the sample is likely due to the colonization characteristics of the city of Santa Maria, Brazil, and does not enable a comparative analysis among the races.

Regarding the periods of tooth eruption, the guidelines of the American Academy of Pediatric Dentistry regarding procedures in pediatric dentistry indicate the eruption and exfoliation chronology described in studies by Logan and Kronfeld (1933). Based on this study, the present sample is slightly ahead with regards to the eruption periods of all tooth groups. According to the study by Marques et al. (1978) on the eruption chronology in the city of São Paulo (SP) mentioned in the Guedes-Pinto book chapter (2016), the eruption periods of permanent teeth vary in some dental groups, but despite the variations found, have a certain order of eruption considered normal for these studied groups. However, the findings were similar to those described by Squef et al. (2008), who evaluated the eruption chronology of the permanent teeth in a population from the city of Porto Alegre (southern Brazil). The corroboration of the results of our study with that of the study by Squef et al. (2008) may be related to regionality, as both studies were developed in the southern region of Brazil, and also with the similarity of sample characteristics, since there is a small number of non-white individuals, which made it impossible to observe differences significant in the eruption chronology of white and non-white individuals in both studies.

Besides sex, other factors can alter the eruption chronology, either delaying or accelerating the process, such as birth weight (VERMA et al., 2017), eating habits (HOLMAN \& YAMAGUCHI, 2005; VERMA et al., 2017), nutrition (BASTOS et al., 2007; HOLMAN \& YAMAGUCHI, 2005), socioeconomic status (BASTOS et al., 2007; VERMA et al., 2017), body mass index (VERMA et al., 2017), heredity (HATTON, 1955), systemic and local diseases (DEAN; AVERY; MCDONALD, 2011; D’AGOSTINO et al., 2020; LIMA et al., 2019), and regionality (HOLMAN \& YAMAGUCHI, 2005; VERMA et al., 2017). Thus, it is observed that the variation in tooth eruption is multifactorial (VERMA et al., 2017). Regarding the dietary pattern, it has been pointed out as an influential factor in the eruption sequence, since changes in the eruption chronology may be influenced by nutritional status, especially energyprotein malnutrition (BRANDÃO \& ROCHA, 2004; HOLMAN \& YAMAGUCHI, 2005). Another factor to consider regarding the difference found in the eruption periods may be related to regionality, since findings can vary when populations of different regions are analyzed, as demonstrated in studies conducted in different parts of the world (OZIEGBE, 2014). In the present study, the children analyzed were healthy and had no syndromes. Therefore, these characteristics were homogeneous within the sample.

In the present study, no significant difference was found between mean chronological age and age determined using Nolla's method, indicating the dental age and chronological age are similar in 
this population. Despite the importance of the results found, we must emphasize that limitations can be observed. The variations found may be related to the regional peculiarities of the studied sample, since all patients are residents of the same city (Santa Maria-RS) and the same educational institution (Universidade Franciscana). Thus, different results may be observed, if a future study is developed, encompassing different regions and different institutions.

\section{FINAL CONSIDERATIONS}

Based on the findings of the present investigation, the sample analyzed was slightly ahead in terms of the eruption periods of all tooth groups in comparison to the periods described in the guidelines of the American Academy of Pediatric Dentistry for procedures and conducts in pediatric practice. Moreover, no significant difference was found in chronological age and dental age determined using Nolla's method (1960) in this population.

Knowledge of the profile of deciduous and permanent eruption of each population is important for such evidence to serve as a basis for the implementation of health prevention and control measures. The sooner the tooth eruption begins, the longer that dental element will be present in the mouth and therefore, the more susceptible to diseases, such as tooth decay. Thus, such actions aim to implement preventive measures, diagnosis and early treatment of diseases and possible oral changes during dental development.

\section{REFERENCES}

BASTOS, J.L. et al. Infant growth, development and tooth emergence patterns: a longitudinal study from birth to 6 years of age. Archives of Oral Biology, v. 52, n. 6, p. 598-606, 2007.

BATH-BALOGH, M.; FEHRENBACH, M. Anatomia, Histologia e Embriologia dos dentes e das estruturas orofaciais. 2. ed. São Paulo: Barueri, 2008.

BRANDÃO, C.F.; ROCHA, M.C.B.S. Cronologia e sequência de erupção dos dentes decíduos em crianças de 0 a 42 meses. Jornal Brasileiro de Odontopediatria \& Odontologia do Bebê, v. 7 , n. 40, p. 528-35, 2004.

D'AGOSTINO, E.S. et al. Chronology and sequence of deciduous teeth eruption in children with microcephaly associated to the Zika virus. Special Care in Dentistry, v. 40, n. 1, p. 3-9, 2020. 
DEAN, J. A.; AVERY, D. R.; MCDONALD, R. E. Erupção dos dentes: Fatores locais, sistêmicos e congênitos que influenciam o processo. In: McDonald e Avery: odontologia para crianças e adolescentes. 9. ed. Rio de Janeiro: Elsevier, p. 148-173, 2011.

GARIB, D. et al. Anomalias dentárias associadas: o ortodontista decodificando a genética que rege os distúrbios de desenvolvimento dentário. Dental Press Journal of Orthodontics, v. 15, n. 2, p. 138-157, 2010.

GOVORKO, D. K.; BECIC, T.; VUKOJEVIC, K. et al. Spatial and temporal distribution of Ki-67 proliferation marker, Bcl-2 and Bax proteins in the developing human tooth. Archives of Oral Biology, v. 55, n. 12, p. 1007-1016, 2010.

GUEDES-PINTO, A.C. Odontopediatria. 7 ed. São Paulo: Santos, 970 p., 2006.

GUEDES-PINTO, A.C. Odontopediatria. 9 ed. São Paulo: Santos, 832 p., 2016.

HATTON, M. E. A Measure of the Effects of Heredity and Environment on Eruption of the Deciduous Teeth. Journal of Dental Research, v. 34, n. 3, p. 397-401, 1955.

HOLMAN, D.J.; YAMAGUCHI, K. Longitudinal analysis of deciduous tooth emergence: IV. Covariate effects in Japanese Children. American Journal of Physical Anthropology, v. 126, p. 352-358, 2005.

LIMA, F.B.D.J.B. et al. A Rare Case of Gorlin-Goltz Syndrome in Children. Case Reports in Dentistry, v. 1, n. 1, p. 1-5, 2019.

LOGAN, W.H.G.; KRONFELD, R. Development of the human jaws and surrounding structures from birth to the age of fifteen years. The Journal of the American Dental Association, v. 20, n . 3, p. $379-427,1933$.

MATALOVÁ, E.; BUCHTOVÁ, M.; TUCKER, A. S. et al. Expression and characterization of c-Myb in prenatal odontogenesis. Development Growth \& Differentiation, v. 53, n. 6, p. 793-803, 2011.

MARQUES, G.D., GUEDES-PINTO, A.C., ABRAMOWICZ, M. Estudo da cronologia de erupção dos dentes permanentes em crianças da cidade de São Paulo. Revista da Faculdade de Odontologia de São Paulo, v. 16, p. 177-186, 1978. 
MCDONALD, R.; DEAN, J.; AVERY, D. Odontopediatria para crianças e adolescentes. 9. ed. Rio de Janeiro: Elsevier Editora Ltda, p. 148-149, 2011.

NOLLA, C. M. The development of permanent teeth. Journal of Dentistry for Children, v. 27, p. 254-266, 1960.

OZIEGBE, E.O. et al. Brief Communication: Emergence Chronology of Permanent Teeth in Nigerian Children. American Journal of Physical Anthropology, v. 153, p. 506-511, 2014.

SEABRA, M. et al. A Importância das Anomalias Dentárias de Desenvolvimento. Acta Pediátrica Portuguesa, v. 39, n. 5, p.195-200, 2008.

SILVA, E. R.; PEREIRA, M. Anomalias dentárias - agenesias e supranumerários - revisão bibliográfica. Journal of Biosciences, v. 21, n. 2, p. 105-13, 2005.

SOSA, M. et al. Anomalías Dentales [Em linha], 2006. Disponível em: http://bvscuba.sld.cu/. Acesso em 31 de out. de 2020.

SQUEF, K. et al. Presença de Dentes Permanentes Irrompidos em Escolares da Região Metropolitana de Porto Alegre. Universidade Luterana do Brasil. Stomatos, v. 14, n. 26, p. 11-18, 2008.

VASCONCELOS, R.G. et al. Desenvolvimento dental: aspectos morfogenéticos e relações com as anomalias dentárias do desenvolvimento. Revista Brasileira de Odontologia, Rio de Janeiro, v. 69, n. 2, p. 232-7, 2012.

VERMA, N. et al. Eruption Chronology in Children: A Cross-sectional Study. International Journal of Clinical Pediatric Dentistry, v. 10, n. 3, p. 278-282, 2017.

WHITE, S.; PHAROAH, M. Radiologia Oral. 5 ed. São Paulo: Elsevier Editora Ltda, p. 346-377, 2007. 
